\title{
IMPLEMENTING DATA-DRIVEN LEARNING INTO ENGLISH GRAMMAR PEDAGOGY: A BASIC INTERPRETATIVE STUDY IN A VOCATIONAL CLASSROOM IN KARAWANG
}

\author{
Abdul Muis Muhyidin \\ SMKN 1 Karawang, West Java \\ Email: abdulmuisamf@gmail.com
}

\begin{abstract}
This study described an implementation of data driven learning in teaching English grammar. To answer of research questions, this study used a qualitative approach with basic interpretative study. The study was conducted in one of vocational high schools in Karawang, involving one English teacher and six students as research subject. To investigate to what extent English teacher applied data-driven learning in teaching English grammar, this study collected data from classroom observation, interviews and studying documents. The results showed that the data driven learning was implemented in teaching grammar through four stages of teaching procedures, including pattern formation through exploring BNC data, explicit explanation from teacher to conform or to correct students' findings, follow-up exercises through homework, then classroom production and teacher's feedback on it.
\end{abstract}

Keywords: teaching grammar, data-driven learning, inductive.

\section{Introduction}

Grammar has a prominent role in language teaching, both in English as a foreign language (EFL) and English as a second language (ESL). Learners' language development will not be fit without a good understanding of grammar. Practically, learners are taught language rules commonly known as sentence patterns and they have to imitate the mentioned sentence based on the language rules.

In the context of Indonesian vocational English classrooms in Karawang, most of English teachers teach grammar traditionally through grammar-translation method, which focuses on translating the target language into native languages or native language into target language. The use of mother language is significantly important to elicit meaning. It can be seen from students' learning activities that they tend to focus on imitating language rules provided by the teacher. In the case of grammar, deductive technique is commonly used. In such technique, students are provided the grammar rules and examples, are told to memorize them, and then are asked to apply the rules to other examples (Widodo, 2006).

Further, in this kind of grammar teaching, teachers only teach how the language is developed in order to construct language properly. In other words, grammar teaching centered on accuracy of form and rule learning, and with mechanical exercises seen as the way to bring about the learning of grammar (Jean \& Simard 2011). As a result, this language pattern makes students passive and they are not interested in grammar, then they are easily bored with learning grammar.

John (1991) introduced the Data Driven Learning and defined it as "the use in the classroom of computer-generated concordances to get students to explore regularities of patterning in the target language, and the development of activities and exercises based on concordance output". It is a student-centered method, which encourages learners to be active in learning process, improves learners' independency and autonomy, enhances language awareness, and makes the learners are able to cope with authentic language. In this style of grammar learning teacher has roles as a guide and an advisor who responsible to direct students and advise on their problem-solving tasks. 
In recent years, some scholars conducted researches on data-driven learning in English language teaching and learning. Previous studies examined data-driven learning for teaching collocation of preposition (Jafarfour \& Koosha, 2005), and data-driven learning in teaching English vocabulary (Guan, 2013). Specifically, Jafarpour \& Koosha (2005) conducted a research on DDL for teaching collocation of preposition with 200 senior English majors studying at three universities in Sharekord. The study found that DDL can enhance students' understanding on collocations of preposition and their sentence production, DDL can be useful for all students in different proficiency level, on the other hand Guan's (2013) study more focus on teaching and learning English vocabulary in China's EFL class. He concluded that data-driven learning encourages students' attention, be conducive to enhance their memory and help them to use context to obtain the word semantics and summarize the grammatical rules.

However, the implementation of grammar instruction through data - driven learning in the Indonesian vocational high school English classes remains under-explored. Therefore, it is essential and interesting to investigate the implementation of data-driven learning in a classroom in Innesian context.

\section{Research Methodology}

This study used qualitative approach by explaining the data set using words, sentences or picture to represent results of this study. It is in line with Bogdan and Biklen (2007) who stated that a qualitative is research procedure which tends to produce descriptive data in the forms of written or spoken from the respondents. Furthermore, the method of this research was basic interpretative study. Since this research aimed at exploring how corpus was used in teaching grammar, a basic interpretative study was utilised. It is in line with Ary, Jacobs, Sorensen \& Razavieh (2010) pointed out that this type of research design aims to describe existing phenomenon.

\section{Research Result}

In this chapter, the researcher presented the result of this study based on the observation, interview and documentation. According to Chujo and Ochigian (2008) there are some general patterns of data-driven learning in the teacher's activities in teaching English grammar. The general patterns were patterns formation through inductive DDL tasks with British national corpus, teacher's explicit explanation to confirm or correct students' findings, follow-up exercises and teacher's feedback (homework), classroom production exercises and teacher's feedback.

Based on the observation, the researcher found some phases applied by English teacher in teaching English grammar through DDL activities, the steps were: Firstly, teacher asked students to work and discuss a particular grammar item by applying British National Corpus (BNC), the discussed material was simple past tense. Teacher commanded students to work in group which consisted of five students in each group. By working in groups, the students could share their discoveries and offer each other support, and were engaged and motivated. They would explore the usage of the grammar points as mentioned, and wrote down the results. The students were commanded to log into BNC corpus online and started to search by initially entering the word did to find out how it was used in the sentence.

After knowing the pattern of did used in negative sentence, the students had to complete the similar procedures to knowing the other form of the word $\mathrm{did}$. The time allotted for this inductive DDL exercises was about 45 minutes.

In the second step, the students reported their discoveries to the class and the teacher elaborated what had been found by students. They explained the use of did in the sentences of simple past tense form, some of them still found some mistakes, like the use of did with verb 2 in negative sentences. Therefore, the teacher gave explicit explanations about the grammar points being 
discussed, in this learning phase, the students had time to confirm and correct their findings they built in the first step. They ensured to the teacher whether their findings were correct or needed to be revised.

In the third step, the teacher gave the students a worksheet of follow-up exercises including consolidation and production tasks for homework, they students were asked to compose five sentences in form of simple past tense, they were asked to elaborate the corpus data deeply at home by utilizing their portable computer or smart phone, this phase allowed them to comprehend simple past tense more. In the fourth step, feedback was given to the follow-up tasks. This was occurred in the next class; the teacher checked the answers to the follow-up activities from the previous class and confirmed their understanding of the language use.

In addition, the researcher conducted an interview with the teacher and the students to strengthen the findings of the research or as triangulation method. The result of the interview with the student is displayed below:

Firstly, we ensure that we have internet access; we open Google, type BNC on the search box, and then type BNC on it, after that the BNC display will appear. Further, we enter a particular word that we want to look for. For instance, we look for the word did, and the screen will show a lot of examples of did in positive, negative, and interrogative. After that we discuss the use of did in the sentence and make conclusion about it. For the next, we explain the result of our discussion, and then the teacher explains about the use of simple past tense. Further, we are given exercise for home work; it is because the time is up. In the next meeting, the teacher gives feedback on our homework and gives additional exercise.

The interview data above illustrated that the teacher applied DDL in teaching English grammar by asking students to log into British national corpus at the first phase of the learning process. In this phase, the students had to discuss a specific grammar point through elaborating BNC data, they search the word did in BNC search box, they had to discuss and make conclusion about the use of did in the sentence. Secondly, the students explained their findings to the class, they explained their discoveries about the use if did in the sentence.

Henceforth, the teacher explained briefly about the grammar point being discussed, the teacher elaborated the use of simple past tense, it was aimed to confirm students' discoveries, and revise some mistake conclusions. Further, due to the limitation of the time, the teacher gave students exercises to be done at home. At the last, the teacher gave feedback on students' works and consolidated the students by giving additional exercises to be completed at home. This final stage was conducted in the second meeting.

\section{Discussion of the Result}

The research was conducted in vocational high school 1 Karawang exactly in X Electronica Engineering which has once English meeting in a week. Based on two meetings observation, the English teacher in this school applied some phases of DDL activities. In the first step, the English teacher instructed students to observe the electronic language data or language examples provided in British National Corpus and notice grammatical patterns freely, while they formed the hypothesis about what they got.

The first learning phase applied by the English teacher is related with Chujo and Ochigian (2008)'s theory about the four steps of DDL activities who stated that the first step of incorporating DDL in teaching English grammar was Hypothesis formation through inductive DDL tasks with BNC corpus.

Moreover, Allen and Valette (1977) stated that the first phase of inductive method in teaching English grammar is examples presentation, the English teachers provide students a series of examples at the first time of learning process, they give some examples that make sense or 
contextual in order to make students can understand that matter easily. It is contrary with deductive learning method (Tornbury, 1999) where students started from the rule or the pattern of language that they want to teach to their students instead of the language examples or language data.

In this first step of DDL activities, the English teacher took more passive roles; meanwhile the students were more active in observing the electronic language data from the BNC website. Dickinson, Brew, \& Meurers (2012) stated that by utilizing technology in language learning, the students can be more active to explore language, they can access a wide range of material in the target language. Then, students are engaging themselves with technology familiar to them (Edwards-Groves, 2012).

From the description, it is clear that the teacher has conducted the first learning phase of inductive learning method. The English teacher asked the students to observe the language data or language examples and make the hypothesis about what they got instead of stating the language patterns or rules, in other word, learners begins the lesson with language examples then formulate and generalize the patterns also make hypotheses at the end of the lesson by themselves (Kim, 2007).

Thus, the students are provided with data which illustrates the use of a grammatical structure which they analyze to generate rules (Ellis, 1997). Then the English teacher has role as a director and collaborator instead of transmitting information to the students directly and explicitly, students have freedom to explore language data, and make the hypothesis of the language rules (Johns, 1988), in other word, the students learn as autonomous learners (Widodo, 2006).

Moreover, the second phase of teacher's activities in teaching English grammar was giving time to students to ask and confirms their findings. The students ensured to the teacher about their hypothesis whether correct or need to be revised. Then the teacher confirmed and explained briefly about the grammatical points which were being discussed. It ensured that all students are looking at and understanding the same thing, which is especially important as they may have observed different phenomena and created divergent hypotheses. In other words, here, the teacher's role was to ensure that all students are on the same page.

According to Chujo and Ochigian (2008) after formatting the hypothesis, the students have time to confirm and correct their hypotheses. The English teacher explains the grammatical rules explicitly. It helps students to comprehend more the language rules that had been found in the first step. In contrary, in deductive teaching method, the second phase in teaching English grammar is highlighting the grammar structures, which means students are supposed to translate their mother language into English as the target language.

The English teacher's activity in third phase was giving students some exercises for homework as follow-up activities, it was conducted to consolidate and check students' understanding. This step is appropriate with Chujo and Ochigian (2008) stated that teacher should check their students' understanding through exercise and consolidation work, it helped students to learn more about the grammar point being discussed.

For the last, the activity was giving feedback on students' homework and giving additional production exercise to be completed in the class, as Chujo and Ochigian (2008) claimed that the last stage for DDL activities is Production through follow-up exercises (in class) and teacher feedback on homework

\section{Conclusion}

Based on findings on the previous chapter, it can be concluded that the teacher's activities in the classroom were students' hypothesis formation through inductive DDL tasks with British National Corpus, Teacher's explicit explanation to confirm or correct students' hypothesis, follow - up activities for homework, and classroom exercises in next meeting.

Therefore, it implies to students' interest in learning English grammar, it helps students to learn 
grammar actively and easily, and then students can comprehend and apply grammar well.

\section{Suggestions}

In order to enrich the result of the research, the researcher as the one who concerns in this research gives some suggestions. These suggestions are addressed to the teacher as key factor in the classroom and other researcher to improve deeper result. The researcher considers some suggestion as follows:

\section{For the English teacher}

The English teacher in vocational high school who already used corpus as the media in teaching especially in teaching English grammar are recommended to apply data driven learning in teaching another language elements, such as using data- driven learning in teaching English vocabulary, which is aimed at learning English vocabulary by implementing technology.

\section{For further research}

In this research, the design of the study that has been designed by the researcher is actually quite simple with embracing qualitatively as basic interpretative study for the research method. Therefore, the further studies are expected to conduct in quantitative approach to know the students' enhancement in applying corpus as media or data-driven learning as the learning method in teaching Englisg grammar. Henceforth, it is recomended to conduct a study qualitatively to gain students' responses toward data- driven learning.

\section{References}

Allen, E. D \& Valette, R.M. (1977). Classroom Techniques: Foreign Languages and English as a Second Language. New York: Harcourt Brace Jovanovich.

Ary, D., Jacobs, L. C., \& Sorensen, C. 2010. Introduction to Research in Education (8th Ed). Wadsworth: Cengage Learning.

Bogdan, R. C., \& Biklen, S. K. (2007). Qualitative Research for Education: An Introduction to Theories and Methods (Fifth ed.). United State of America: Pearson International Edition.

Chujo, K. \& Oghigian, K. (2008). A DDL approach to learning noun and verb phrases in the beginner level EFL classroom. In A. Frankenberg-Garcia (Ed.) Proceedings of the 8th Teaching and Language Corpora Conference, (pp. 65-71). Lisbon, Portugal: Associação de Estudos e de Investigação Cientifíca do ISLA-Lisbo Fichier.

Dickinson, M., Brew, C., \& Meurers, D. (2012). Language and Computers. Retrieved from http:// www.eblib.com . accessed on $10^{\text {th }}$ of May 2017

Edwards-Groves, C. (2012). Interactive creative technologies: Changing learning practices and pedagogies in the writing classroom. Australian journal of language and literacy, 35 (1), 99.

Ellis, R. (1997). SLA research and language teaching. Oxford: Oxford University Press.

Guan, X. (2013). A Study on the Application of Data-driven Learning in Vocabulary Teaching and Leaning in China's EFL Class. Journal of Language Teaching and Research, 4(1), 105-112.

Jafarpour, A.A., \& Koosha, M. (2005). Data-driven Learning and Teaching collocation of prepositions: The case of Iranian EFL Students. Research on Foreign Languages learning: the role of corpus consultation literacy," ReCALL 19(3): 269-86.

Jean, G. \& D. Simard (2011). Grammar learning in English and French L2: Students' and teachers' beliefs and perceptions. Foreign Language Annals 44.4, 465-492.

Johns, T. (1988). Whence and Whither Classroom Concordancing? In P. Bongearts/ P. de Hann/ $\mathrm{S}$. Lobbe/ H. Wekker (eds). Computer applications in language learning. Dordrecht: Foris, 9-27. 
Johns, T. (1991). Should you be persuaded: two examples of data driven learning. ELR Journal,4, $1-16$.

Kim, J. (2007). A comparative study of the effects of explicit- inductive/cooperative instruction versus explicit-deductive/individualistic instruction on the second language acquisition of English relative clauses in Korean university-level EFL learners (Doctoral dissertation). Language Teaching. Cambridge University Press.

Thornbury, S. (1999). How to Teach Grammar. Harlow: Longman

Widodo, H. (2006). Approaches and procedures for teaching grammar. English Teaching, 5(1), 121 